\title{
Growth patterns of Palestinian children from birth to 24 months
}

\author{
Ali Albelbeisi ${ }^{1}$, Zalilah Mohd Shariff ${ }^{1}$, Chan Yoke Mun ${ }^{1}$, Hejar Abdul-Rahman ${ }^{2}$ and Yehia Abed ${ }^{3}$
}

${ }^{1}$ Department of Nutrition and Dietetics; ${ }^{2}$ Department of Community Health, Faculty of Medicine and Health Sciences, Universiti Putra Malaysia, Serdang, Selangor, Malaysia (Correspondence to: Zalilah M. Shariff: zalilahms@upm.edu.my). ${ }^{3}$ Department of Public Health, Faculty of Public Health, Al Quds University, Gaza, Palestine.

\begin{abstract}
Background: Growth faltering in early life can adversely affect health in later childhood and adulthood. Growth monitoring of children can provide evidence to help formulate effective strategies to address growth problems but such information on Palestinian children is lacking.

Objectives: This study aimed to determine the growth patterns of children under 2 years in Gaza, Palestine.

Methods: This retrospective cohort study was conducted in 2014 in 10 randomly selected primary health care clinics in 5 governorates of Gaza. Weight and length data were obtained from the health cards of children born in 2012, and z-scores were calculated and compared with the WHO Growth Standard (2006).

Results: A total of 2632 children's cards were included at the beginning of the study. Weight-for-age and weight-forlength decreased from birth to 6 months to about -0.40 SD but increased afterwards to -0.11 SD and 0.34 SD at 24 months respectively. Length-for-age declined after 6 months, reaching - 0.85 SD at 24 months. At 6 months, the prevalence of underweight and stunting were $5 \%$ and $9 \%$ but at 24 months, the prevalence was $4 \%$ and $20 \%$ respectively. Wasting was highest at 6 months (10\%) but decreased to $3 \%$ at 24 months. Significantly more girls were stunted at 9,12 and 18 months $(P<0.001)$, underweight at 24 months $(P<0.05)$ and wasted at 12 months $(P<0.05)$. Early life faltering in length was more pronounced than weight, with stunting occurring in one fifth of boys and girls by 2 years of age.

Conclusions: Preventive strategies are urgently needed to address early life causes of undernutrition, particularly stunting, in Palestinian children in Gaza.

Keywords: Young children, growth faltering, underweight, stunting, wasting

Citation: Albelbeisi A; Mohd Shariff Z; Chan YM; Abdul Rahman H; Abed Y. Growth patterns of Palestinian children from birth to 24 months. East Mediterr Health J. 2018;24(3):302-310. https://doi.org/10.26719/2018.24.3.302

Received: 26/01/17; accepted: 22/05/17

Copyright (c) World Health Organization (WHO) 2018. Some rights reserved. This work is available under the CC BY-NC-SA 3.0 IGO license (https:// creativecommons.org/licenses/by-nc-sa/3.o/igo).
\end{abstract}

\section{Introduction}

Undernutrition is the underlying cause of death in $45 \%$ of all deaths among children under 5 years of age (1). The global prevalence of stunting, underweight and wasting among children under 5 years has been reported to be $23 \%, 14 \%$ and $10 \%$ respectively, with most undernourished children are living in Asia and Africa $(2,3)$. In developing countries, $29.9 \%, 19.4 \%$ and $10 \%$ of children under 5 years were stunted, underweight and wasted respectively $(4,5)$. In the Middle East, 3.9\%, 9.7\%, and $4.4 \%$ of children under 5 years were reported to be underweight, stunted and wasted respectively (5). In Palestine, stunting (10.3\%) remains the most prevalent form of undernutrition among children under 5 years, followed by underweight (2.5\%) and wasting (2.4\%) (6).

The first 2 years of life are characterized by high energy and nutrient requirements to meet the needs for growth and development (7-9). Inadequate dietary quality and frequent infections are important risk factors for undernutrition in young children $(10,11)$. Infants in low- and middle- income communities often experience growth faltering in the first 2 years of life and evidence suggests that growth faltering commonly starts at 4-6 months of age (12-14). Data from developing countries show that faltering in weight often starts around 4 months whereas stunting starts from birth (15). Growth faltering in early life can adversely affect health in later childhood and adulthood with effects ranging from cognitive deficits to risk of chronic diseases (16-18).

Growth monitoring of children facilitates early identification of growth deviation and the period of greatest risk for malnutrition. With such information, effective strategies can be formulated to address the specific growth problem (19). As growth information on Palestinian young children is lacking, this study was conducted to track the growth status of children from birth to 2 years so as to inform the growth patterns and prevalence of undernutrition of children during this critical period of growth.

\section{Methods}

\section{Study setting, design and subjects}

This retrospective cohort study was conducted from April to June 2014 in 10 randomly selected primary health care clinics in 5 governorates of the Gaza Strip. Five clinics were selected from 20 clinics of the United Nations Relief and Work Agency (UNRWA) and another 5 clinics from 54 
clinics of the Ministry of Health (MoH). Each governorate was represented by 1 UNRWA and $1 \mathrm{MoH}$ clinic. A total of 8852 health cards of children born in the year 2012 were available in these 10 clinics and were screened for study eligibility (healthy, i.e. no physical disability and diseases, appropriate for gestational age). The sample size calculation was based on the World Health Organization formula. A prevalence of wasting of $34.3 \%$ among children under 2 years in Gaza and a 1.9\% margin of error were used in the calculation $(20,21)$. The minimum sample size was 2382 , and a total of 2650 health cards were selected (10\% more cards were added in case of excluded children who had a biologically improbable anthropometric observation, and to improve precision). Upon screening, 6463 health cards were eligible for the study from which 2650 health cards were randomly selected in proportion to the percentages of refugee and non-refugee children in each governorate. Random sampling of clinics and health cards was done using a computerized table of random numbers.

\section{Measurements}

In both UNRWA and $\mathrm{MoH}$ clinics, each newborn is assigned a health card which contains information on sociodemographics, birth, medical conditions, schedule of vaccination and growth monitoring (birth to 2 years). In clinics, recumbent weight and length of children are measured by nurses using standard techniques for children 2 years and below. Portable infant electronic scales (Seca Chica 345) and paediatric length measuring mats (Seca 210) arre used to measure recumbent weight and length respectively. Growth data are available at birth, $6,9,12,15,18$ and 24 months on the child health card. In this study, age and sex-specific z-scores for weight-forage (WAZ), length-for-age (LAZ) and weight-for-length (WLZ) of the children were calculated using WHO Anthro software (version 3). Underweight, stunting and wasting for children were defined as WAZ, LAZ and WLZ below 2 standard deviations (SD) of the median (22).

\section{Ethics approval}

The study protocol was approved by the Ethics Committee for Research Involving Human Subjects of the Faculty of Medicine and Health Sciences, Universiti Putra Malaysia and the Helsinki Ethics Committee of Gaza Strip. Permissions to conduct the study in $\mathrm{MoH}$ and UNRWA clinics were obtained from the Department of General Administration and Human Resources Development and the Health Affairs Centre of UNRWA respectively.

\section{Data analysis}

SPSS for Windows, version 21, was used for data analysis. Descriptive statistics were used to describe continuous and categorical data. The chi-squared test was used to examine the association between prevalence of undernutrition and gender. Subjects were excluded (18 at birth, 61 at 6 months, 68 at 9 months, 52 at 12 months, 43 at 15 months, 28 at 18 months and 3 at 24 months) when one of their anthropometric observations was considered to be biologically improbable according to the cut-offs defined by the World Health Organization (19). Specifically, the cut-offs are LAZ $<-5$ SD or $>+3$ SD, WAZ $<-5$ SD or $>+5$ SD or WLZ $<-4$ SD or $>+5$ SD.

\section{Results}

A total of $2632(2650-18)$ children were included at the beginning of the study, 1307 (49.7\%) boys and 1325 (50.3\%) girls (Table 1). The proportions of children from the 5 governorates were 920 (35.0\%) (Gaza), 511 (19.4\%) (North), 376 (14.3\%) (Middle), 503 (19.1\%) (Khanyounis) and 322 (12.2\%) (Rafah). The median birth weight and length were $3.30 \mathrm{~kg}$ and $50 \mathrm{~cm}$ respectively. A total of 1016 (38.6\%) children were born at the 40th week of gestation and the median gestational age was 39 (SD 0.93) weeks. The

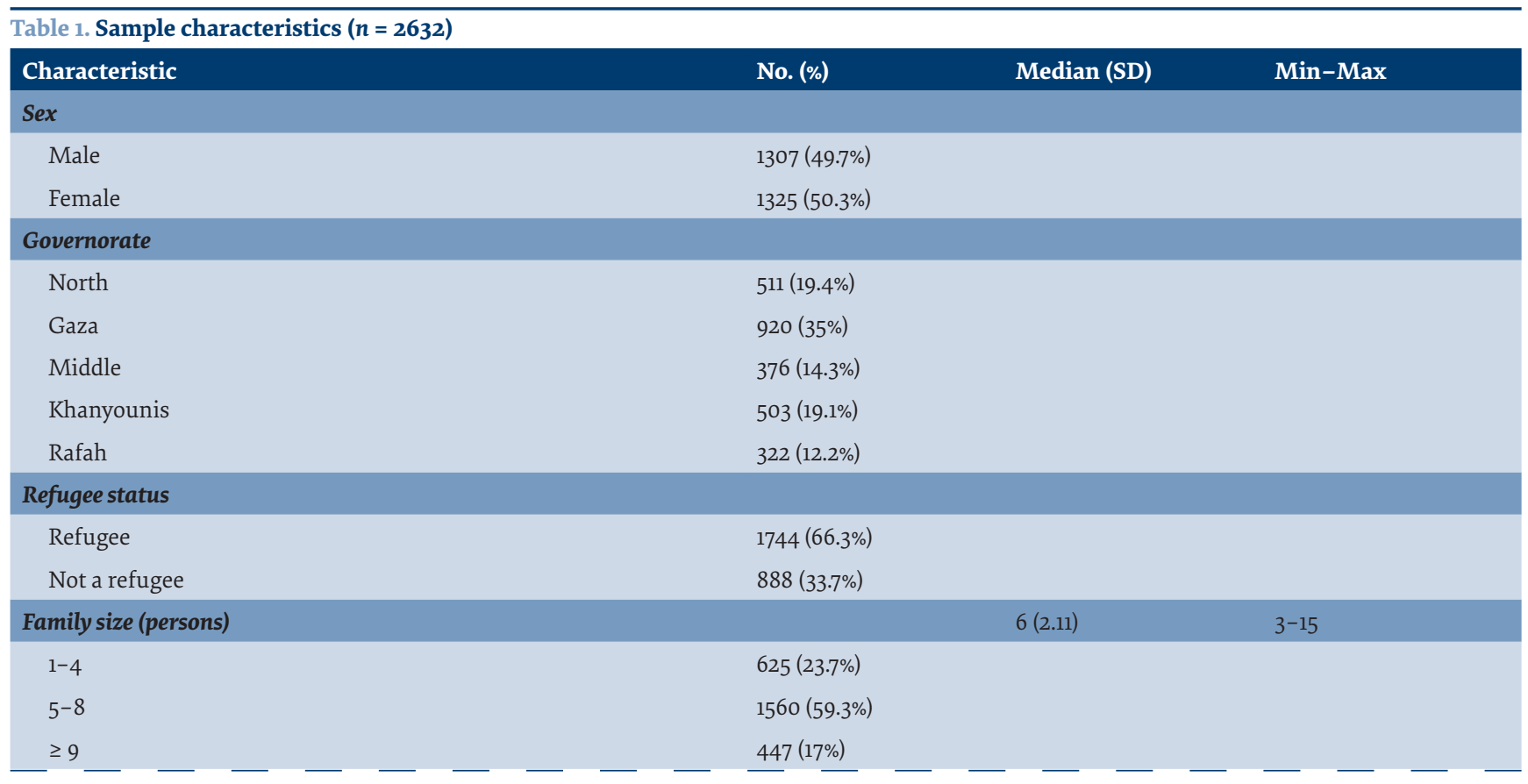




\begin{tabular}{|c|c|c|c|}
\hline Characteristic & No. (\%) & Median (SD) & Min-Max \\
\hline \multicolumn{4}{|l|}{ Mother's employment status } \\
\hline Working & $191(7.3 \%)$ & & \\
\hline Housewife & $2441(92.7 \%)$ & & \\
\hline \multicolumn{4}{|l|}{ Father's employment status } \\
\hline Working & $2241(85.2 \%)$ & & \\
\hline Not working & $391(14.8 \%)$ & & \\
\hline \multicolumn{4}{|l|}{ Educational level } \\
\hline Illiterate or read and write only & $0(0 \%)$ & & \\
\hline Primary school & $806(30.6 \%)$ & & \\
\hline Secondary school & $813(30.9 \%)$ & & \\
\hline Above secondary school & $1013(38.5 \%)$ & & \\
\hline \multicolumn{4}{|l|}{ Number of siblings (persons) } \\
\hline $1-3$ & $1144(43.5 \%)$ & $4(2.11)$ & \\
\hline $4-6$ & $1041(39.5 \%)$ & & \\
\hline$\geq 7$ & $449(17 \%)$ & & \\
\hline Birth weight $(\mathrm{kg})$ & & $3.30(0.29)$ & $2.55-3.90$ \\
\hline Birth length (cm) & & $50.0(1.84)$ & $45.50-53.50$ \\
\hline \multicolumn{4}{|l|}{ Gestational age (weeks) } \\
\hline 38 & $584(22.2 \%)$ & $39(0.93)$ & \\
\hline 39 & $774(29.4 \%)$ & & \\
\hline 40 & $1016(38.6 \%)$ & & \\
\hline 41 & $258(9.8 \%)$ & & \\
\hline \multicolumn{4}{|l|}{ Age breastfeeding stopped (months) } \\
\hline $6-8.9$ & $696(26.4 \%)$ & $10(2.31)$ & $6-18$ \\
\hline $9-11.9$ & $1304(49.6 \%)$ & & \\
\hline $12-14.9$ & $474(18 \%)$ & & \\
\hline $15-17.9$ & $152(5.8 \%)$ & & \\
\hline$\geq 18$ & $6(0.2 \%)$ & & \\
\hline
\end{tabular}

$S D=$ standard deviation

median age of infants when breastfeeding stopped was 10 (SD 2.31) months, with 2000 (76.0\%) mothers stopping breastfeeding before their infant reached 12 months of age.

Table 2 presents the median $z$-scores for WAZ, LAZ and WLZ of the children. The trends of WAZ, LAZ and WLZ from birth to 24 months are shown in Figure 1. In the first 6 months of life, the median WAZ and WLZ were lower than LAZ. Specifically, WAZ at birth was below the median (-0.07 SD), declined further to -0.35 SD at 6 months but increased thereafter and remained relatively stable by 24 months. LAZ started above the median (0.06 SD) at birth, increased to $0.17 \mathrm{SD}$ at 6 months but declined thereafter, reaching $-0.85 \mathrm{SD}$ at 24 months. At birth, WLZ was $-0.17 \mathrm{SD}$, decreased to $-0.40 \mathrm{SD}$ at 6 months but increased to above the median by 12 months and increased slightly thereafter.

Figure 2 illustrates the prevalence of undernutrition by age and sex of the children. None of the children was underweight, stunted or wasted at birth. From 6 to 24 months, while the prevalence of underweight was relatively stable $(\sim 5 \%)$, there was a decreasing trend in the prevalence of wasting (10\% to $2.8 \%$ ) but an increasing trend for stunting prevalence (9\% to 20.4\%) (Figure 2a). A significantly greater proportion of girls were stunted than boys at 9,12 and 18 months $(P<0.001)$ but at 24 months the proportion was similar for boys (20.1\%) and girls (20.6\%) (Figure 2b). More boys than girls were underweight at 9 months $(P<0.001)$ but by 24 months, underweight was significantly more prevalent in girls (5.0\%) compared with boys $(3.4 \%)(P<0.05)$ (Figure $2 \mathrm{c})$. The proportion of girls and boys with wasting was similar for at all time points except at 12 months where wasting was more prevalent in girls $(P<0.05)$ (Figure $2 d)$.

\section{Discussion}

Undernutrition in Palestine is largely determined by the worsening political and socioeconomic conditions in the country (23). In 2013, the Palestinian Central Bureau of Statistics reported that 11 out of 100 children under 5 years suffered chronic malnutrition or stunting (23). The prevalence of stunting in Palestine increased from $7.5 \%$ in 2000 to $10.9 \%$ in 2010 with the Gaza Strip recording a stunting prevalence of $10.4 \%$ (23). In 2010, a United 


\begin{tabular}{|c|c|c|c|c|c|c|c|}
\hline Variable & At birth & 6 months & 9 months & 12 months & 15 months & 18 months & 24 months \\
\hline Weight (kg) & $\begin{array}{c}3.30 \\
\text { (2.55 to } 3.90)\end{array}$ & $\begin{array}{c}7.20 \\
\text { (4.30 to } 11.50)\end{array}$ & $\begin{array}{c}8.30 \\
(4.80 \text { to } 13.20)\end{array}$ & $\begin{array}{c}9.20 \\
\text { (6.50 to } 14.80)\end{array}$ & $\begin{array}{c}10 \\
\text { (6.90 to } 15.30)\end{array}$ & $\begin{array}{c}10.50 \\
\text { (6.60 to } 15.80)\end{array}$ & $\begin{array}{c}11.50 \\
\text { (7.80 to } 16.50)\end{array}$ \\
\hline Length $(\mathrm{cm})$ & $\begin{array}{c}50 \\
\text { (45.5 to } 53.5)\end{array}$ & $\begin{array}{c}67 \\
\text { (56 to } 72 \text { ) }\end{array}$ & $\begin{array}{c}71 \\
\text { (62 to } 77)\end{array}$ & $\begin{array}{c}75 \\
\text { (63 to } 81.6 \text { ) }\end{array}$ & $\begin{array}{c}78 \\
\text { (65 to } 85)\end{array}$ & $\begin{array}{c}81 \\
\text { (66.5 to } 89)\end{array}$ & $\begin{array}{c}84 \\
\text { (71.7 to 95) }\end{array}$ \\
\hline WAZ & $\begin{array}{c}-0.07 \\
(-1.78 \text { to } 1.37)\end{array}$ & $\begin{array}{c}-0.35 \\
(-4.14 \text { to } 3.49)\end{array}$ & $\begin{array}{c}-0.23 \\
(-4.35 \text { to } 3.74)\end{array}$ & $\begin{array}{c}0.05 \\
(-3.52 \text { to } 4.07)\end{array}$ & $\begin{array}{c}-0.09 \\
(-3.57 \text { to } 3.67)\end{array}$ & $\begin{array}{c}-0.03 \\
(-3.89 \text { to } 3.34)\end{array}$ & $\begin{array}{c}-0.11 \\
(-3.61 \text { to } 2.67)\end{array}$ \\
\hline LAZ & $\begin{array}{c}0.06 \\
(-2.05 \text { to } 2.34)\end{array}$ & $\begin{array}{c}0.17 \\
(-4.50 \text { to } 2.97)\end{array}$ & $\begin{array}{c}-0.06 \\
(-4.89 \text { to } 2.84)\end{array}$ & $\begin{array}{c}-0.18 \\
(-4.10 \text { to } 2.85)\end{array}$ & $\begin{array}{c}-0.06 \\
(-4.57 \text { to } 2.73)\end{array}$ & $\begin{array}{c}-0.25 \\
(-4.89 \text { to } 2.87)\end{array}$ & $\begin{array}{c}-0.85 \\
(-4.92 \text { to } 2.57)\end{array}$ \\
\hline WLZ & $\begin{array}{c}-0.17 \\
(-3.97 \text { to } 3.76)\end{array}$ & $\begin{array}{c}-0.40 \\
(-3.61 \text { to } 4.81)\end{array}$ & $\begin{array}{c}-0.09 \\
(-3.88 \text { to } 4.35)\end{array}$ & $\begin{array}{c}0.18 \\
(-3.90 \text { to } 4.07)\end{array}$ & $\begin{array}{c}0.17 \\
\text { (- } 4 \text { to } 3.83)\end{array}$ & $\begin{array}{c}0.18 \\
(-3.98 \text { to } 3.81)\end{array}$ & $\begin{array}{c}0.34 \\
(-3.96 \text { to } 3.77)\end{array}$ \\
\hline
\end{tabular}

Values are median (range).

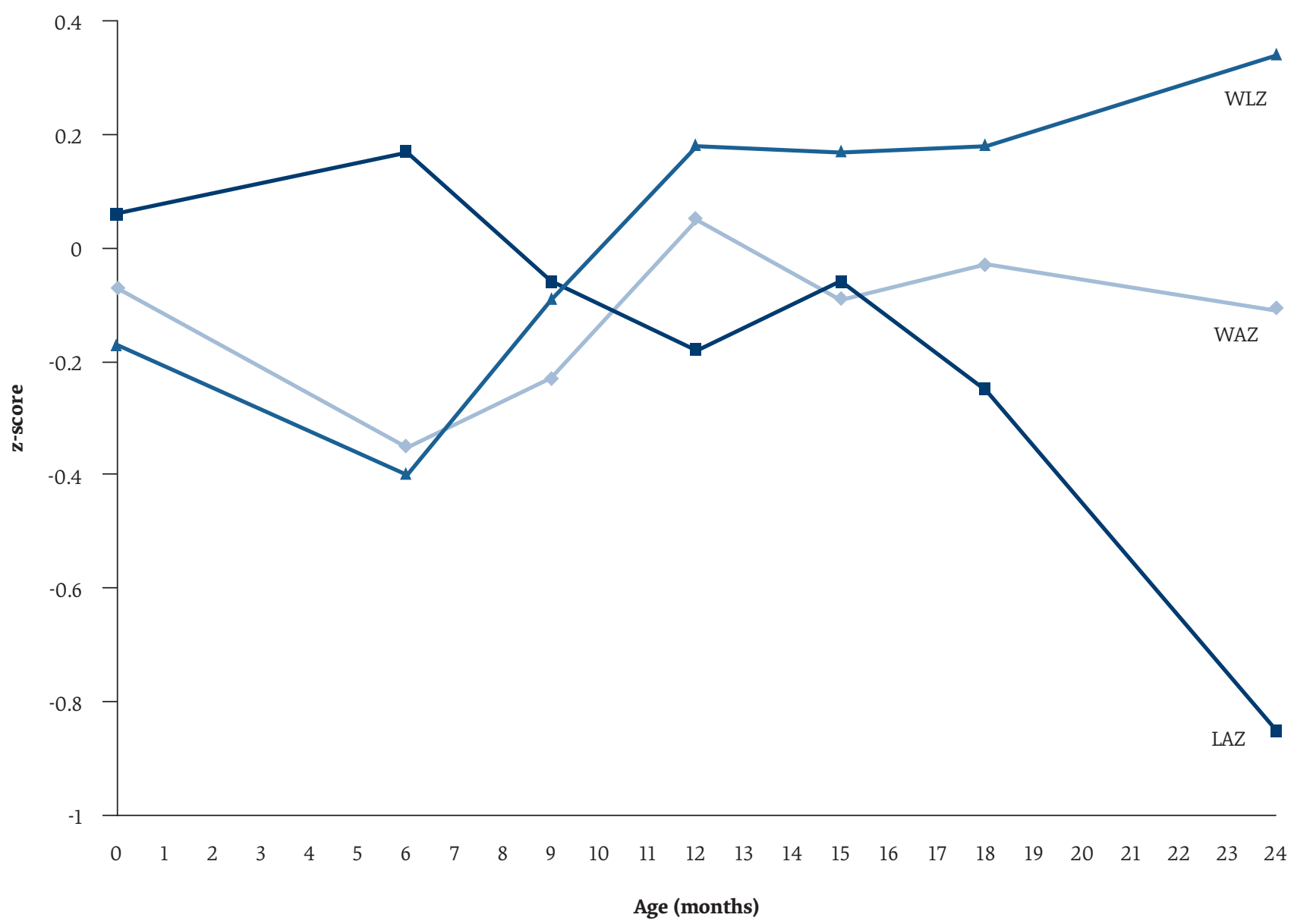

Figure 1 Median anthropometric z-scores of Gazan children relative to the World Health Organization growth standards. Sample: $n=2650$; subjects were excluded when one of their anthropometric observations was considered to be biologically improbable (18 were excluded at birth, 61 at 6 months, 68 at 9 months, 52 at 12 months, 43 at 15 months, 28 at 18 months and 3 at 24 months)

Nations Children's Fund (UNICEF) report indicated that the prevalence of stunting among children under 5 years of age had increased from a national average of $7 \%$ in 2004 to $10 \%$ in 2006 , with a significant difference between the West Bank (8\%) and the Gaza Strip (13\%) (24). In recent years, stunting has been the most prevalent form of undernutrition $(\sim 10 \%)$ as compared to underweight and wasting in Gazan children under 5 years $(24,25)$. Our study showed that stunting prevalence at 24 months was
2 times greater than reported in previous studies (23-25), although underweight and wasting rates prevalence were similar.

In our study, the proportion of undernutrition was significantly more prevalent in girls compared with boys. A review of child health differences in 15 Arab countries showed that girls had a higher rate of stunting than boys in 5 countries, including Palestine, and girls had 


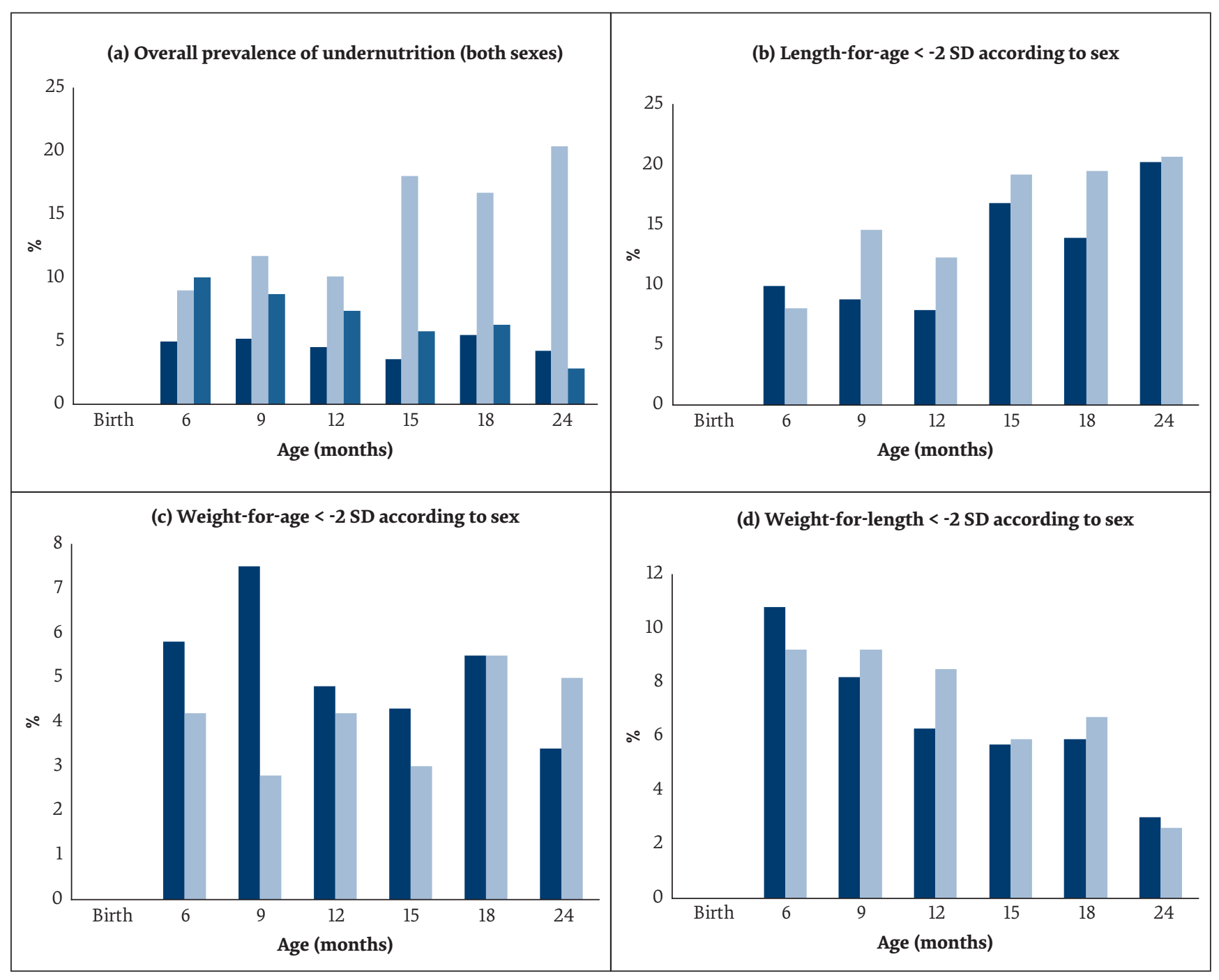

Figure 2 Prevalence of undernutrition among Gazan children: $2 b$ shows significant differences in prevalence at 9,12 and 18 months $(P$ $<0.001) ; 2$ shows significant difference in prevalence at $9(P<0.001)$ and $24(P<0.05)$ months; and $2 d$ shows significant difference in prevalence at 12 months $(P<0.05)$

a significantly higher rate of wasting in Jordan, Sudan and Tunisia (26). In 2003, the Palestinian Central Bureau of Statistics showed that the prevalence of stunting and underweight among Palestinian girls was higher than boys (27). However, the 2010 Palestinian family survey showed that the prevalence of underweight, stunting and wasting among boys under 5 years was higher than that in girls (28). Similarly, studies in Africa have reported that the rate of undernutrition among boys was consistently higher than that in girls $(29,30)$. Important determinants of such differences included low socioeconomic status, older siblings of a similar gender, birth order and gender bias $(31,32)$. Therefore, a possible reasons for the gender disparities in Palestine could be low socioeconomic status, the family set-up, and gender bias.

We showed that WAZ and WLZ of Gazan children faltered from birth to 6 months but increased thereafter. LAZ however, increased from birth to 6 months but declined after this age. An analysis of growth faltering among children under 5 years in 54 developing countries showed that height-for-age (HAZ) and WAZ were slightly below the standard mean at 1 month and faltered thereafter until 24 months, with the growth faltering pattern more pronounced for LAZ than WAZ. In contrast, weight-for-height (WHZ) started above the standard mean but faltered slightly until 9 months and increased thereafter to around the standard mean by 24 months of age (14). For countries in North Africa and the Middle East, the analysis further showed that WAZ, HAZ and WHZ in Egypt increased from 1 month to 12 months but declined thereafter. In Jordan, WAZ and HAZ started above the standard mean but gradually declined to $-0.41 \mathrm{SD}$ and -0.74 SD respectively at 59 months. On the other hand, WHZ showed a fluctuating pattern of decrease and increase with the z-scores well above the standard mean. Similar to our results, in both countries, HAZ faltering was more pronounced than WAZ and WHZ (14).

There are several explanations for the observed growth faltering in children under 2 years in the Gaza Strip. Sub-optimum breastfeeding and frequent infections can contribute to weight and length faltering in the first 6 months of life (33). The 2014 survey of the 
Palestinian Central Bureau of Statistics_reported that exclusive breastfeeding rates averaged at $38.6 \%$ from birth to 5 months of age (34). Growth faltering among Palestinian children could also be attributed to the early introduction of complementary foods. A study published in 2007 reported that about $62 \%$ of children under 5 years in the Gaza Strip received complementary foods before 6 months of age (35). Lower weight-for-age, length-for-age, and higher risk of infections are significantly associated with early feeding of complementary foods to infants (36-38). In addition, food insecurity has been shown to adversely affect the growth status of children under 5 year $(39,40)$. In the Occupied Palestinian Territories, food insecurity continues to be prevalent and about $85 \%$ of the population are food insecure $(41,42)$. Gordon and Halileh in 2013 reported the determinants of stunting among 9051 Palestinian children aged $<5$ years; these were: lower birth weight $(P<0.001)$, age $>12$ months $(P$ $<0.001)$, higher levels of food insecurity $(P<0.001)$, lower household socioeconomic index $(P<0.001)$, maternal illiteracy $(P<0.01)$, and absence of supplementation to breastfeeding during the first 4 months of the life $(P<$ $0.05)(43)$.
Because of time constraints, our study was conducted retrospectively. Retrospective designs have a number of limitations which may lead to the exclusion of some subjects from contributing to the study, and the possibility of observational bias arising from measurements or documenting errors. Therefore, we used a large sample and excluded subjects who had improbable measurements from the analysis.

Our study showed that stunting, a form of chronic undernutrition, was prevalent among the children under 2 years in the Gaza Strip, Palestine. Promoting adequate antenatal and postnatal care, breastfeeding and appropriate complementary feeding practices is important because length faltering has important health consequences for infants and young children. In a resource-constrained setting such as the Gaza Strip, timely micronutrient supplementation or food fortification could also improve the health and nutrition of these children. Further studies, however, are needed to ascertain specific nutrition interventions that could effectively prevent growth faltering among children under 2 years in the Gaza Strip.

\section{Acknowledgement}

We thank the staff at the MOH and UNRWA health care clinics for their support and cooperation in the study.

Funding: None.

Competing interests: None declared.

\section{Schémas de croissance des enfants palestiniens de la naissance à l'âge de 24 mois}

\section{Résumé}

Contexte : Le ralentissement de la croissance en début de vie peut avoir un impact négatif sur la santé plus tard dans l'enfance et à l'âge adulte. Le suivi de la croissance des enfants fournit des données permettant d'élaborer des stratégies efficaces pour lutter contre les problèmes de croissance, mais de telles données n'existent pas pour les enfants palestiniens.

Objectifs: La présente étude visait à déterminer les schémas de croissance des enfants de moins de deux ans à Gaza (Palestine).

Méthodes : Cette étude de cohorte rétrospective a été conduite en 2014 auprès de 10 dispensaires de soins de santé primaires sélectionnées au hasard dans cinq gouvernorats de Gaza. Les données sur le poids et la taille ont été obtenues à partir de carnets de santé d'enfants nés en 2012, et les z-scores ont été calculés et comparés à l'aide des Normes OMS de croissance (2006).

Résultats : Au total, 2632 carnets de santé d'enfants ont été inclus au début de l'étude. Le poids pour l'âge et le poids pour la taille baissaient entre la naissance et six mois jusqu'à environ -0,40 écart type, mais augmentaient ensuite en passant à $-0,11$ ET à 0,34 ET respectivement à l'âge de 24 mois. La taille pour l'âge chutait après 6 mois, et atteignait $-0,85$ ET à 24 mois. À 6 mois, la prévalence du déficit pondéral et du retard de croissance était de $5 \%$ et $9 \%$, mais à 24 mois elle était de $4 \%$ et $20 \%$ respectivement. L'émaciation était la plus élevée à 6 mois (10\%), mais passait à $3 \%$ à 24 mois. Un nombre significativement plus élevé de filles présentait un retard de croissance, à 9,12 et 18 mois ( $p<0,001)$, ainsi qu'un déficit pondéral à 24 mois $(p<0,05)$ et une émaciation à 12 mois $(p<0,05)$. Le ralentissement de la croissance affectant la taille en début de vie était plus prononcé que celui du poids, avec une émaciation survenant chez un cinquième des garçons et des filles âgées de 2 ans.

Conclusions : Des stratégies de prévention sont requises de toute urgence afin de lutter contre les causes de dénutrition en début de vie, et particulièrement contre le retard de croissance, chez les enfants palestiniens de Gaza. 


\section{أنهاط نمو الأطفال الفلسطينيين حتى سن \& Y شهراً \\ علي البلبيسي، زليلة شريف، شان من، هيجر عبد الرحمن، يجيى عابد \\ الخالاصة الباني}

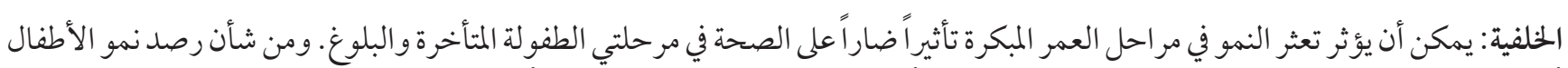

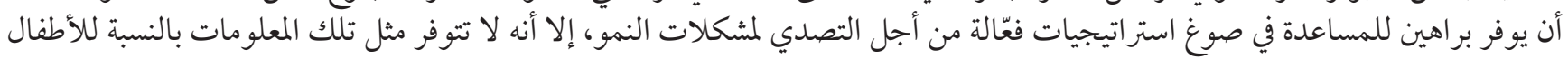
الفلسطينين.

$$
\text { الأهداف: هدفت هذه الدراسة إلى تحديد أنماط نمو الأطفال دون السنتين في قطاع غزة بفلسطين. }
$$

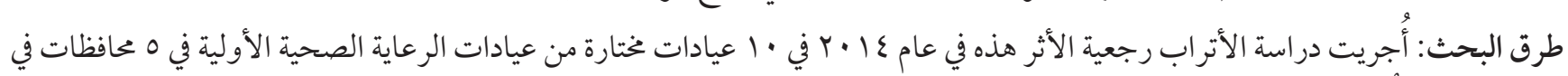

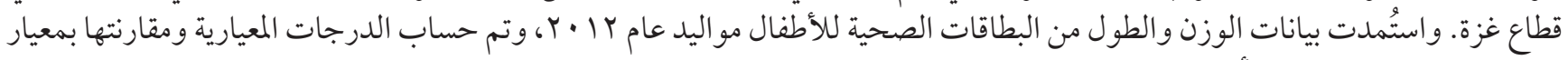

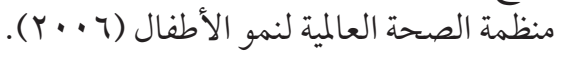

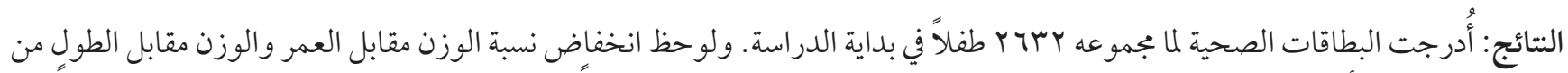

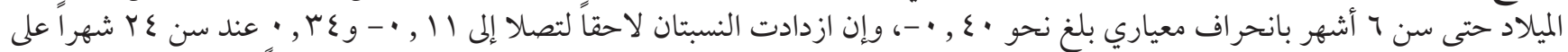

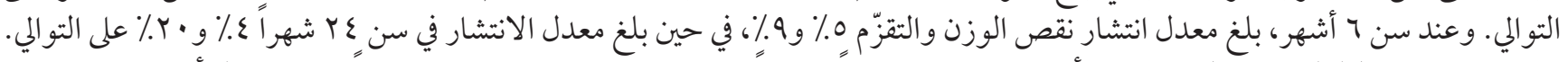

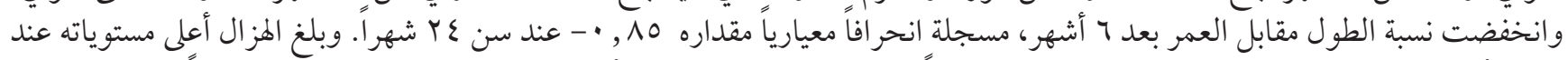

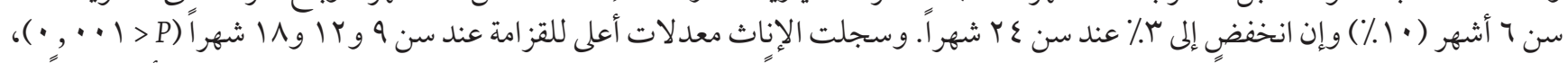

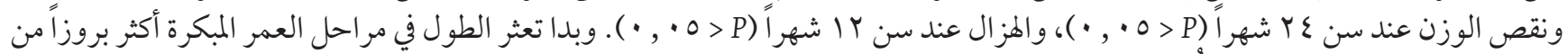

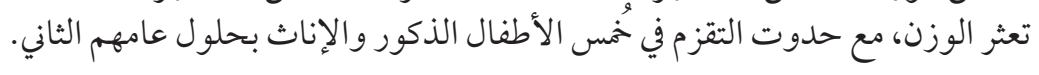

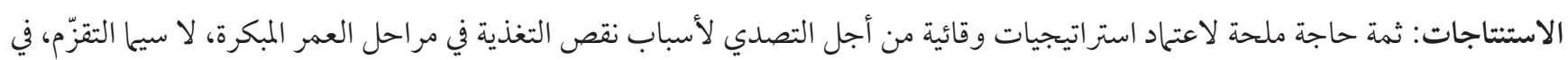
صفوف الأطفال الفلسطينيين في غزة.

\section{References}

1. World Health Organization. Media centre. Children: reducing mortality. Fact sheet. Updated October 2017 (http://www.who.int/ mediacentre/factsheets/fs178/en/, accessed 19 November 2017).

2. UNICEF. Monitoring the situation of children and women. Undernutrition contributes to nearly half of all deaths in children under 5 and is widespread in Asia and Africa (http://data.unicef.org/topic/nutrition/malnutrition/, accessed 19 November 2017).

3. World Health Organization. Global Health Observatory data repository. Global and regional trends by WHO Regions, $1990-2016$. Underweight (http://apps.who.int/gho/data/view.main.NUTWHOUNDERWEIGHTv, accessed 19 November 2017).

4. Progress for children: a world fit for children. Statistical review. New York: UNICEF; 2007 (https://www.unicef.org/progressforchildren/2007n6/files/Progress_for_Children_-_No._6.pdf, accessed 19 November 2017).

5. Levels and trends in child malnutrition. UNICEF-WHO-World Bank. Joint Child Malnutrition Estimates. New York: UNICEF, Geneva: WHO, Washington, DC: The World Bank; 2012 (http://www.who.int/nutgrowthdb/jme_unicef_who_wb.pdf, accessed 19 November 2017).

6. Abdeljawad A, Humeid JM. Nutritional status of Palestinian children under five (6-59 months) in three governorates of the Gaza Strip: a rapid assessment study. Paper presented at the Siege and Mental Health... Walls vs. Bridges International Conference, 27-29 October, 2008, Gaza City, Palestine.

7. Victora CG, Adair L, Fall C, Hallal PC, Martorell R, Richter L, et al.; Maternal and Child Undernutrition Study Group. Maternal and child undernutrition: consequences for adult health and human capital. Lancet. 2008 Jan 26;371(9609):340-57. http://dx.doi. org/10.1016/S0140-6736(07)61692-4 PMID:18206223

8. Arnold F, Parasuraman S, Arokiasamy P, Kothari M. Nutrition in India. National Family Health Survey (NFHS-3), India, $205-2006$. Mumbai: International Institute for Population Sciences \& Calverton, Maryland, USA; 2009.

9. Butte NF. Energy requirements of infants. Public Health Nutr. 2005 Oct;8(7A) 7a:953-67. http://dx.doi.org/10.1079/PHN2005790 PMID:16277814

10. Goulet O. Growth faltering: setting the scene. Eur J Clin Nutr. 2010 May;64 Suppl 1:S2-4. http://dx.doi.org/10.1038/ejcn.2010.38 PMID:20442721

11. Black RE, Allen LH, Bhutta ZA, Caulfield LE, de Onis M, Ezzati M, et al.; Maternal and Child Undernutrition Study Group. Maternal and child undernutrition: global and regional exposures and health consequences. Lancet. 2008 Jan 19;371(9608):243-60. http://dx.doi.org/10.1016/S0140-6736(07)61690-0 PMID:18207566

12. Maleta K, Virtanen S, Espo M, Kulmala T, Ashorn P. Timing of growth faltering in rural Malawi. Arch Dis Child. 2003 Jul;88(7):574-8. http://dx.doi.org/10.1136/adc.88.7.574 PMID:12818899

13. Neumann CG, Harrison GG. Onset and evolution of stunting in infants and children. Examples from the Human Nutrition Collaborative Research Support Program. Kenya and Egypt studies. Eur J Clin Nutr. 1994 Feb;48 Suppl 1:S90-102. PMID:8005095 
14. Victora CG, de Onis M, Hallal PC, Blössner M, Shrimpton R. Worldwide timing of growth faltering: revisiting implications for interventions. Pediatrics. 2010 Mar;125(3):e473-80. doi: 10.1542/peds.2009-1519 PMID:20156903

15. Shrimpton R, Victora CG, de Onis M, Lima RC, Blössner M, Clugston G. Worldwide timing of growth faltering: implications for nutritional interventions. Pediatrics. 2001 May;107(5):E75. http://dx.doi.org/10.1542/peds.107.5.e75 PMID:11331725

16. Dewey KG, Begum K. Long-term consequences of stunting in early life. Matern Child Nutr. 2011 Oct;7 Suppl 3:5-18. http://dx.doi. org/10.1111/j.1740-8709.2011.00349.x PMID:21929633

17. Hoddinott J, Behrman JR, Maluccio JA, Melgar P, Quisumbing AR, Ramirez-Zea M, et al. Adult consequences of growth failure in early childhood. Am J Clin Nutr. 2013 Nov;98(5):1170-8. http://dx.doi.org/10.3945/ajcn.113.064584 PMID:24004889

18. Lanigan J, Singhal A. Early nutrition and long-term health: a practical approach. Proc Nutr Soc. 2009 Nov;68(4):422-9. http://dx. doi.org/10.1017/So02966510999019X PMID:19698202

19. Physical status: the use and interpretation of anthropometry: Report of a WHO Expert Committee. Geneva: World Health Organization; 1995 (WHO Technical Report Series, 854).

20. World Health Organization. Chronic diseases and health promotion. STEPS sample size calculator and sampling spreadsheet. 2008 (http://www.who.int/chp/steps/resources/sampling/en/, accessed 30 November 2017).

21. Radi S, Mourad TA, Papandreou C. Nutritional status of Palestinian children attending primary health care centers in Gaza. Indian J Pediatr. 2009 Feb;76(2):163-6. https://doi.org/10.1007/s12098-009-0046-9 PMID:19330304

22. WHO Child Growth Standards: Length/height-for-age, weight-for-age, weight-for-length, weight-for-height and body mass index-for-age: Methods and development. Geneva: World Health Organization; 2006 (http://www.who.int/childgrowth/standards/Technical_report.pdf, accessed 19 November 2017).

23. Palestinian children - issues and statistics. Annual report, 2013. Child Statistics Series (No. 16). Ramallah: Palestinian Central Bureau of Statistics; 2013 (http://www.pcbs.gov.ps/Downloads/book1971.pdf, accessed 19 November 2017).

24. The situation of Palestinian children in the Occupied Palestinian Territory, Jordan, Syria and Lebanon: An assessment based on the Convention on the Rights of the Child. New York: UNICEF; 2010.

25. Tsigga M, Grammatikopoulou MG. Assessing the silent epidemic of malnutrition in Palestinian preschool children. J Epidemiol Glob Health. 2012 Dec;2(4):181-91. http://dx.doi.org/10.1016/j.jegh.2012.12.002 PMID:23856499

26. Khawaja M, Dawns J, Meyerson-Knox S, Yamout R. Disparities in child health in the Arab region during the 1990s. Int J Equity Health. 2008 Nov 20;7:24. https://doi.org/10.1186/1475-9276-7-24 PMID:19021903.

27. Health Survey 1996. Ramallah, Palestinian Central Bureau of Statistics; 2003.

28. Palestinian Family Survey 2010. Ramallah: Palestinian Central Bureau of Statistics; 2013 (http://www.pcbs.gov.ps/Downloads/ book1941.pdf, accessed 30 November 2017).

29. Kabubo-Mariara J, Ndenge GK, Mwabu DK. Determinants of children's nutritional status in Kenya: evidence from demographic and health surveys. J. Afr. Econ. 2009;18(3):363-87. https://doi.org/10.1093/jae/ejno24

30. Lwambo N, Brooker S, Siza J, Bundy D, Guyatt H. Age patterns in stunting and anaemia in African schoolchildren: a cross-sectional study in Tanzania. Eur J Clin Nutr. 2000 Jan;54(1):36-40. PMID:10694770.

31. Dey I, Chaudhuri R. Gender inequality in nutritional status among under five children in a village in Hooghly district, West Bengal. Indian J Public Health. 2008;52(4):218-20. PMID:19189827

32. Pande RP. Selective gender differences in childhood nutrition and immunization in rural India: the role of siblings. Demography. 2003;40(3):395-418. PMID:12962055

33. Black RE, Allen LH, Bhutta ZA, Caulfield LE, de Onis M, Ezzati M, et al.; Maternal and Child Undernutrition Study Group. Maternal and child undernutrition: global and regional exposures and health consequences. Lancet. 2008 Jan 19;371(9608):243-60. http://dx.doi.org/10.1016/S0140-6736(07)61690-o PMID:18207566

34. Palestinian multiple indicator cluster Survey 2014: monitoring the situation of children and women. Ramallah: Palestinian Central Bureau of Statistics; 2015 (https://mics-surveys-prod.s3.amazonaws.com/MICS5/Middle\%20East\%20and\%20North\%20Africa/ State\%200f\%20Palestine/2014/Final/State\%20of\%20Palestine\%202014\%20MICS_English.pdf, accessed 30 November 2017).

35. El-Kariri M, Kanoa B. Infant feeding in Gaza Strip: mother knowledge, attitudes and practices. Annals of Alquds Medicine. 2007;3(1428):58-65.

36. Kimani-Murage EW, Madise NJ, Fotso JC, Kyobutungi C, Mutua MK, Gitau TM, et al. Patterns and determinants of breastfeeding and complementary feeding practices in urban informal settlements, Nairobi Kenya. BMC Public Health. 2011 05 26;11(1):396. http://dx.doi.org/10.1186/1471-2458-11-396 PMID:21615957

37. Kalanda BF, Verhoeff FH, Brabin BJ. Breast and complementary feeding practices in relation to morbidity and growth in Malawian infants. Eur J Clin Nutr. 2006 Mar;60(3):401-7. http://dx.doi.org/10.1038/sj.ejcn.1602330 PMID:16306929

38. Tessema M, Belachew T, Ersino G. Feeding patterns and stunting during early childhood in rural communities of Sidama, South Ethiopia. Pan Afr Med J. 2013 Feb 26;14:75. http://dx.doi.org/10.11604/pamj.2013.14.75.1630 PMID:23646211

39. Ali D, Saha KK, Nguyen PH, Diressie MT, Ruel MT, Menon P, et al. Household food insecurity is associated with higher child undernutrition in Bangladesh, Ethiopia, and Vietnam, but the effect is not mediated by child dietary diversity. J Nutr. 2013 Dec;143(12):2015-21. http://dx.doi.org/10.3945/jn.113.175182 PMID:24089419 
40. Psaki S, Bhutta ZA, Ahmed T, Ahmed S, Bessong P, Islam M, et al.; for MALED Network Investigators. Household food access and child malnutrition: results from the eight-country MAL-ED study. Popul Health Metr. 2012 12 13;10(1):24. http://dx.doi. org/10.1186/1478-7954-10-24 PMID:23237098

41. Radi SM, El-Sayed NA, Nofal LM, Abdeen ZA. Ongoing deterioration of the nutritional status of Palestinian preschool children in Gaza under the Israeli siege. East Mediterr Health J. 2013 Mar;19(3):234-41. PMID:23879074

42. United Nations World Food Programme and Food and Agricultural Organization of the United Nations. West Bank and Gaza Strip: Comprehensive food security and vulnerability analysis. January 2007:18 (https://unispal.un.org/pdfs/CFSVA_WBGS.pdf, accessed 19 November 2017).

43. Gordon NH, Halileh S. An analysis of cross sectional survey data of stunting among Palestinian children less than five years of age. Matern Child Health J. 2013 Sep;17(7):1288-96. http://dx.doi.org/10.1007/s10995-012-1126-4 PMID:22948964 